Tropical Journal of Pharmaceutical Research October 2015; 14(10): 1919-1926

ISSN: $1596-5996$ (print); 1596-9827 (electronic)

(C) Pharmacotherapy Group, Faculty of Pharmacy, University of Benin, Benin City, 300001 Nigeria.

All rights reserved.

Available online at http://www.tjpr.org

Original Research Article

http://dx.doi.org/10.4314/tjpr.v14i10.26

\title{
Assessment of Tigecycline Prescription and Patients' Outcomes at Three Different Hospitals in Saudi Arabia
}

\author{
Mansour Tobaiqy ${ }^{1,2 \star}$, Saad Al Humaid ${ }^{3}$, Derek Stewart ${ }^{4}$, Fayez Omear Alotaibi ${ }^{5}$, \\ Kamal Ahmad Qureshi ${ }^{6}$, Katie MacLure ${ }^{4}$, Fahad Algharib ${ }^{3}$, Ahmed Alsameti ${ }^{3}$, \\ Ahmed Alsaqer ${ }^{3}$ and Ahmad Almeman ${ }^{7}$ \\ ${ }^{1}$ Patient Safety, Maternity and Children's Hospital, Ministry of Health, Jeddah, ${ }^{2}$ Department of Pharmacology, Faculty of \\ Medicine, University of Jeddah, Jeddah, ${ }^{3}$ Administration of Pharmaceutical Care, Alhassa, Saudi Arabia, ${ }^{4}$ School of Pharmacy \\ and Life Sciences, Robert Gordon University, Aberdeen, United Kingdom, ${ }^{5}$ Department of Inpatient Pharmacy, King Fahad \\ Jeddah Hospital, Jeddah, ${ }^{6}$ Department of Microbiology, College of Pharmacy Unizah, ${ }^{7}$ Department of Pharmacology \& \\ Therapeutics, College of Medicine, University of Qassim, Qassim, Saudi Arabia
}

*For correspondence: Email: m.tobaiqy@moh.gov.sa

Received: 15 May 2015

Revised accepted: 6 September 2015

\begin{abstract}
Purpose: To investigate tigecycline prescription and patient outcomes in the Kingdom of Saudi Arabia (KSA).

Methods: A retrospective observational study was conducted in three KSA government hospitals, between January, 2013 and May, 2014. The patients were identified from electronic prescription records; data were retrieved by trained researchers.

Results: Thirty-seven patients who received tigecycline were included (mean age, 52.5 years; range, 17 92); $51.4 \%$ were female. Tigecycline was prescribed for sepsis (59.5\%), pneumonia (21.6\%), and/or intra-abdominal infections (13.5\%). The majority of the patients $(86.5 \%)$ were prescribed tigecycline in intensive care unit (ICU) and the remaining patients were in the general medical ward. APCHE II score at the beginning of treatment was $16.8 \pm 4.3$, indicating severe disease. Susceptibility testing revealed 22 different bacterial pathogens, most commonly Acinetobacter baumannii (20 patients) and Klebsiella pneumoniae (14 patients). A significant proportion (56.7\%) was polymicrobial and 16.2 $\%$ involved suspected resistant pathogens. Sixteen patients recovered (5 on tigecycline alone, 5 with additional antimicrobials, and six switched to alternatives) while 21 patients died (nine on tigecycline alone, 12 with additional antimicrobials).

Conclusions: The study revealed that tigecycline prescription was conducted according to marketing authorizations and national guidelines. Infection severity/stage and comorbidities may influence patients' response, and explain some of the poor outcomes.
\end{abstract}

Keywords: Kingdom of Saudi Arabia, Prescription patterns, Mortality, Tigecycline, Antimicrobial

Tropical Journal of Pharmaceutical Research is indexed by Science Citation Index (SciSearch), Scopus, International Pharmaceutical Abstract, Chemical Abstracts, Embase, Index Copernicus, EBSCO, African Index Medicus, JournalSeek, Journal Citation Reports/Science Edition, Directory of Open Access Journals (DOAJ), African Journal Online, Bioline International, Open-J-Gate and Pharmacy Abstracts

\section{INTRODUCTION}

Bacterial infections present an increasing and well-recognized challenge to clinical practice for several reasons: the rapid emergence of resistant strains [1]; medication over-prescription in all healthcare settings [2,3]; and ethical issues, for example inappropriate patient demands [4]. Furthermore, the empirical antibacterial therapy without sufficient intelligence in relation to pathogen susceptibility has been linked to increased fatality in patients with sepsis [5]. The discovery and development of truly novel antibacterials by the pharmaceutical industry has 
declined markedly, primarily due to scientific complexity and resource implications [6]. Tigecycline is one of the very few unique agents launched in the last decade, with initial introduction in the United States (US) in 2005 [7]. The US Food and Drug Administration (FDA) licensed tigecycline for the treatment of patients with skin and soft tissue infections, complicated intra-abdominal infections, and communityacquired pneumonia [8]; followed by the European Medicine Agency (EMA) licensing in 2006 [9].

Tigecycline circumvents mechanisms of bacterial resistance via a modification of the central structure of minocycline by the addition of a 9-tbutyl-glycylamido side chain. This renders tigecycline effective against a wide range of gram-positive and gram-negative organisms, notably highly resistant pathogens such as methicillin-resistant Staphylococcus aureus, Staphylococcus epidermidis, vancomycinresistant Enterococcus species, extended spectrum $\beta$-lactamase producers (ESBL), Clostridium difficile and many carbapenemaseproducing Enterobacteriaceae; however, it has no activity against Proteus or Pseudomonas species $[10,11]$. It exhibits a linear pharmacokinetic profile, a large volume of distribution $\mathrm{Vd}(7 \mathrm{l} 10 \mathrm{~L})$, a half-life of $37-67 \mathrm{~h}$, and clearance of $0.2-0.3 \mathrm{~L} / \mathrm{h} / \mathrm{kg}[12,13]$. In adults, it is administered intravenously as a loading dose of $100 \mathrm{mg}$, followed by $50 \mathrm{mg}$ every $12 \mathrm{~h}$, with dose-reduction recommended in cases of sever hepatic impairment as in Child-Pugh Class C. Adverse drug reactions include: nausea (26\%), vomiting (18\%), diarrhea (12\%), abdominal pain $(6 \%)$, headache $(6 \%)$, and increased serum glutamic pyruvic transaminase levels $(<2 \%)[14]$.

Two main concerns of tigecycline have become apparent recently: the emerging clinical resistance [15] and life-threatening adverse events [16] which have been confirmed by independent meta-analyses of all-cause mortality data $[17,18]$. Studies conducted in Europe [19] and Taiwan [20] have demonstrated largely, an appropriate use of tigecycline in terms of its licensed indications and dosage, highlighting the need to balance patients' risks and benefits.

Tigecycline was introduced to the Saudi market in 2008 to treat skin, soft-tissue, and intraabdominal infections. In August, 2011, the Saudi Food and Drug Authority (SFDA) issued a safety notification advising that tigecycline should only be prescribed for licensed indications and as a last resort, where alternative antimicrobials were deemed inappropriate [21].

\section{METHODS}

\section{Study design}

A retrospective observational study was conducted in several hospitals. This study was approved by the Ethical Committee of the Ministry of Health Research Centre in Jeddah, KSA. All the three hospitals must comply with local prescription guidelines for tigecycline: the prescription should be initiated by a medical consultant; pathogen susceptibilities should be determined by laboratory analyses; and the prescription should be authorized by an infectious diseases physician, a microbiologist, and a pharmacist.

\section{Study setting and participants}

The study was conducted in three main KSA governmental hospitals: King Fahad Hofuf Hospital (KFHH); King Fahad Jeddah Hospital (KFJH); and King Fahad Specialist Hospital (KFSH), located in the regional provinces of Makkah, Al-Ahsa, and Qassim, respectively. Each hospital has 500-900 beds and mainly serves adult patients. All patients prescribed tigecycline between January 2013 and May 2014 were included in the study, with no exclusions.

\section{Data collection and analysis}

The patients prescribed tigecycline were identified from electronic prescription data. A data collection template was developed and piloted to record the following: patient demographics (age, sex, weight, hospital); past medical history; adverse drug reactions, allergies, medication history (including current medication); reason for admission to hospital (signs, symptoms); Acute Physiology and Chronic Health Evaluation (APACHE II) disease severity score [22]; tigecycline indication and regimen (dose, route, duration); documented adverse events; renal and hepatic function; microbiological analyses of pathogen susceptibility; ongoing monitoring (documented clinical response); and clinical safety endpoints (documented recovery, surgery, readmission). The data were entered into SPSS (SPSS Inc., Cary, NC version 22.0) and analyzed using descriptive statistics. Missing data were recorded for all variables considered. Three hospital pharmacists attended researcher training sessions to receive information about the purpose of the research and the data collection process. The data were collected from the patients' electronic medical records in $\mathrm{KFSH}$ and $\mathrm{KFHH}$, and from paper-based medical records in 
$\mathrm{KFJH}$, where electronic records had not been fully implemented at the time of this study.

\section{RESULTS}

Thirty-seven patients were included: 18 in $\mathrm{KFHH}$; 11 in $\mathrm{KFJH}$; and 8 in $\mathrm{KFBH}$. The mean patient age was 52.5 years (SD \pm 21.4 , range 17 92) and $19(51.4 \%)$ were female. The demographics at the start of tigecycline therapy, disease severity scores, and comorbidities, as shown in Table 1. Thirty-two patients $(86.5 \%)$ were

Table 1: Summary of patients' characteristics and reasons for tigecycline use

\begin{tabular}{|c|c|c|c|}
\hline Characteristics & All patients & Improved $^{a}$ & Died $^{D}$ \\
\hline Number of patients & $37(100 \%)$ & $16(43.2 \%)$ & $21(56.8 \%)$ \\
\hline Mean Age (SD) & 52.5 (21.4) & 56.18 (16.37) & $52.7(24.01)$ \\
\hline Women, n (\%) & 19 (51.4\%) & $5(26.3 \%)$ & $14(73.7 \%)$ \\
\hline \multicolumn{4}{|l|}{ Comorbidities, $n(\%)$} \\
\hline HTN & 17 (17.3\%) & $4(23.5 \%)$ & 13 (76.5\%) \\
\hline DM & $16(16.3 \%)$ & $6(37.5 \%)$ & $10(62.5 \%)$ \\
\hline Heart (CHF, IHD, MVS, MVR, LVH, LBBB) & $13(13.3 \%)$ & $3(23.1 \%)$ & 10 (76.9\%) \\
\hline Renal (ARF, CKD, ESRD, other) & $12(12.3 \%)$ & $3(25 \%)$ & $9(75 \%)$ \\
\hline Old CVA & $6(6.2 \%)$ & $1(16.7 \%)$ & $5(83.3 \%)$ \\
\hline $\begin{array}{l}\text { Other (amputated leg, bed-ridden, psychosis, } \\
\text { piles, thrombocytopenia, warfarin overdose) }\end{array}$ & $6(6.2 \%)$ & $2(33.3 \%)$ & $4(66.6 \%)$ \\
\hline $\begin{array}{l}\text { Neurological (brain atrophy, multiple brain } \\
\text { contusions, PD, CP) }\end{array}$ & $4(4.1 \%)$ & $2(50 \%)$ & $2(50 \%)$ \\
\hline ASP & $4(4.1 \%)$ & $1(25 \%)$ & $3(75 \%)$ \\
\hline Epilepsy & $3(3.1 \%)$ & $2(66.6 \%)$ & $1(33.3 \%)$ \\
\hline Respiratory (asthma, COPD, IPF) & $3(3.1 \%)$ & $1(33.3 \%)$ & $2(66.6 \%)$ \\
\hline PE & $2(2.0 \%)$ & - & $2(100 \%)$ \\
\hline MR & $2(2.0 \%)$ & - & $2(100 \%)$ \\
\hline SCA & $2(2.0 \%)$ & - & $2(100 \%)$ \\
\hline Muscular (DMD, rhabdomyolysis) & $2(2.0 \%)$ & $1(50 \%)$ & $1(50 \%)$ \\
\hline Autoimmune/inflammatory (RA, SLE) & $2(2.0 \%)$ & $1(50 \%)$ & $1(50 \%)$ \\
\hline Infectious (TB, HCV) & $2(2.0 \%)$ & - & $2(100 \%)$ \\
\hline Vascular (DIC) & $1(1.0 \%)$ & $1(100 \%)$ & - \\
\hline Cancer & $1(1.0 \%)$ & $1(100 \%)$ & - \\
\hline \multicolumn{4}{|l|}{ Severity/organ dysfunction scores } \\
\hline APACHE II score, $n$ & 43 & 11.3 & 31.7 \\
\hline mean \pm standard deviation (range) & $\begin{array}{l}16.8 \pm 4.3 \\
(0-28)\end{array}$ & $8.7 \pm 5.5(0-11)$ & $\begin{array}{l}22.1 \pm 7.6 \\
(4-28)\end{array}$ \\
\hline$\leq 15, n(\%)$ & $11(25.6)$ & $7(61.9)$ & $5(15.8)$ \\
\hline$\leq 15$, mean (median) & $7(8.8)$ & $12.4(13.7)$ & $11.6(14.3)$ \\
\hline$>15, n(\%)$ & $23(67.6)$ & $3(8.8)$ & $20(58.8)$ \\
\hline$>15$, mean (median) & $8.3(9.7)$ & $11.1(12.6)$ & $16.1(18.4)$ \\
\hline missing/unknown, $n$ & 3 & 1 & 2 \\
\hline \multicolumn{4}{|c|}{$\begin{array}{l}\text { Reasons for tigecycline use, alone or in combination, in all patients } \\
\text { Reason, } n(\%)^{c}\end{array}$} \\
\hline Failure of previous therapy ${ }^{a}$ & $5(13.5 \%)$ & $1(20 \%)$ & $4(80 \%)$ \\
\hline Suspected resistant pathogens & $6(16.2 \%)$ & $3(50 \%)$ & $3(50 \%)$ \\
\hline $\begin{array}{l}\text { Need broad-spectrum coverage/polymicrobial } \\
\text { infection }\end{array}$ & $21(56.7 \%)$ & $9(42.9 \%)$ & $12(57.1 \%)$ \\
\hline Allergy to/intolerance of previous antibacterial & $2(5.4 \%)$ & $1(50 \%)$ & $1(50 \%)$ \\
\hline Renal impairment & $3(8.1 \%)$ & $2(66.7 \%)$ & $1(33.3 \%)$ \\
\hline Others & NA & - & 10 \\
\hline
\end{tabular}

Abbreviations: APACHE II, Acute Physiology and Chronic Health Evaluation score; ARF, acute renal failure; $A S P$, aspiration pneumonia; CHF, congestive heart failure; CKD, chronic kidney disease; COPD, chronic obstructive pulmonary disease; $C P$, cerebral palsy' DIC, disseminated intravascular coagulopathy; DM, diabetes mellitus; DMD, Duchenne muscular dystrophy; ESRD, end-stage renal disease; HTN, hypertension; HCV, hepatitis $C$ virus; IHD, ischemic heart disease; IPF, interstitial pulmonary fibrosis; $L B B B$, left bundle branch block; $L V H$, left ventricular hypertrophy; MR, mental retardation; MVR, mitral valve stenosis; MVS, mitral valve regurgitation; NA, not available; $P D$, Parkinson's disease; $P E$, pulmonary edema; RA, rheumatoid arthritis; $S C A$, sickle-cell disease; SLE, systemic lupus erythematosus; TB, tuberculosis. ${ }^{a}$ Improvement was defined as a clinical cure or response without additional antibiotic. ${ }^{b}$ Death was defined as failure or no improvement with additional antibiotic. ${ }^{c}$ Patients could have more than one reason. ${ }^{d}$ Previous therapy included all treatments that were given prior to tigecycline 


\section{Use of tigecycline in 3 KSA hospitals and the treatment outcome}

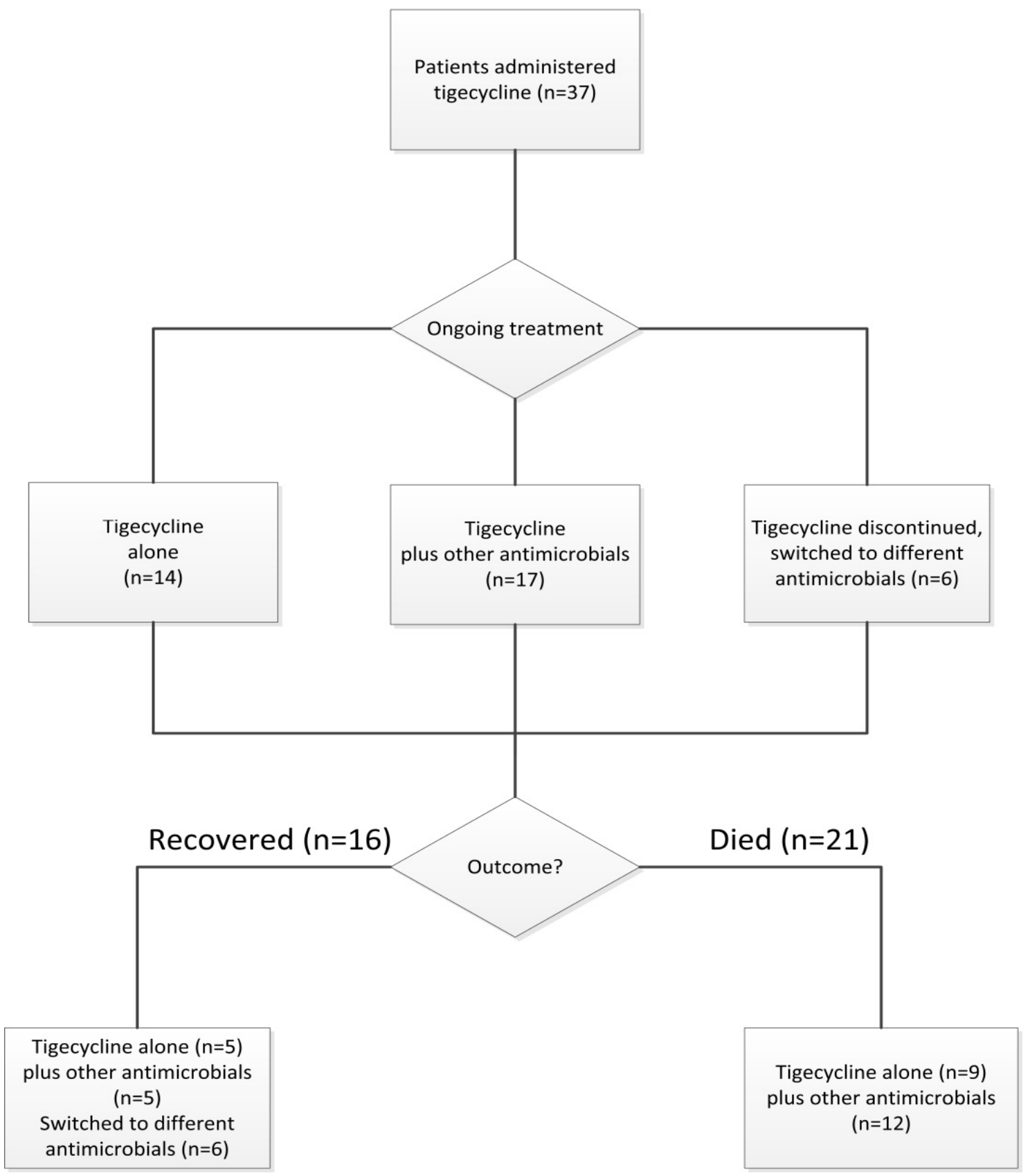

Figure 1: Treatment and outcomes of patients prescribed tigecycline $(n=37)$

Table 2: Tigecycline indications $(n=37)$

\begin{tabular}{lc}
\hline Indication & patients \\
\hline Sepsis & 59.5 \\
Community-acquired bacterial pneumonia & 21.6 \\
Intra-abdominal infection & 13.5 \\
Suspected community-acquired bacterial pneumonia & 10.8 \\
Wound infections (abscess, gangrene, diabetic foot and bed sores) & 10.8 \\
Urinary tract infection & 2.7 \\
Cystic fibrosis & 2.7 \\
\hline
\end{tabular}


Table 3: Identified bacterial pathogens $(n=74)$

\begin{tabular}{lc}
\hline Gram-positive pathogens & $\mathbf{n}$ \\
\hline Enterococcus faecalis & 3 \\
Staphylococcus aureus & 1 \\
Staphylococcus epidermidis & 1 \\
Methicillin-resistant Staphylococcus aureus & 1 \\
Streptococcus anginosus & 1 \\
Staphylococcus saprophyticus & 1 \\
Viridans streptococci & 1 \\
\hline Gram-negative pathogens & \\
\hline Acinetobacter baumannii & 20,3 resistant \\
Klebsiella pneumonia & 14 \\
Pseudomonas aeruginosa & 11,2 resistant \\
Escherichia coli & 4,2 resistant \\
Proteus mirabilis & 4 \\
ESBL-producing Enterobacteriaceae & 3 \\
Serratia marcescens & 2 \\
Providencia stuartii & 1 \\
Morganella morganii & 1 \\
ESBL-producing Klebsiella pneumoniae & 1 \\
Klebsiella oxytoca & 1 \\
Enterobacter cloacae & 1 \\
Pseudomonas luteola & 1 \\
Citrobacter freundii & 1 \\
\hline
\end{tabular}

treated with tigecycline in the intensive care unit (ICU) and the remaining proportion of patients were in the medical wards. Biochemical monitoring prior to commencing tigecycline, identified three patients with impaired renal function; there was no evidence of impaired hepatic function.

The documented indications for tigecycline are given in Table 2, with some patients having more than one indication. None of the patients had been treated previously for similar infections.

\section{DISCUSSION}

Tigecycline is a very few unique antimicrobial agents which was launched in the last decade, with initial introduction to the US in 2005. Two main concerns of tigecycline have become apparent since its launch; emerging clinical resistance and life-threatening adverse events. Tigecycline was introduced to the KSA market in 2008.

This study showed that tigecycline prescription patterns within these hospitals in the KSA were mostly in line with the guidelines [7,9]; it was reserved and prescribed for clearly defined indications at appropriate initiation and maintenance doses $[7,11,22]$. This is in line with the previous studies in Taiwan [19] and Europe [20]. Tigecycline was initiated under the instruction of a consultant in according to the recommended dosing schedule of $100 \mathrm{mg}$ intravenously initially, followed by $50 \mathrm{mg}$ every
12 hours (except one patient with renal insufficiency received $50 \mathrm{mg}$ followed by $25 \mathrm{mg}$ every $12 \mathrm{~h}$ ). The treatments and patients' outcomes are shown in Figure 1.

However, we identified tigecycline usage for some unapproved indications that both the SFDA and FDA have issued warnings against; these included diabetic foot, urinary tract infections, undefined pneumonia, and septic shock.

These dangerous pathogens are acknowledged to pose the greatest therapeutic challenges and, while often drug-resistant, may respond to tigecycline $[23,24]$. Other studies in the KSA reported that $20 \%$ of Acinetobacter baumannii cases showed an increased resistance in 2011, as compared to $10 \%$ in 2010 [25,26]. A range of pathogens were isolated, reflecting the complexity of the required therapeutic plans. Interestingly, tigecycline was also effective in patients infected with Serratia marcescens, previously reported to be resistant to tigecycline [27], and similarly in a patient infected with Klebsiella pneumoniae [28,29].

Of the 37 patients prescribed tigecycline, 16 recovered (five on tigecycline alone, five with additional antimicrobials, and six who switched to alternatives) and 21 died, 14 were confirmed with Klebsiella pneumonia, (nine on tigecycline alone, twelve with additional antimicrobials). In 2011, the SFDA warned of a high death risk if tigecycline is used for pneumonia, or any unapproved indications [21]. A further 
confirmation by the FDA was released in 2013 warning against the increased risk of death in approved and unapproved indications, stating that tigecycline should only be used when necessary [16]. Ten out of the 16 patients, continued on tigecycline therapy, and the other 6 were changed to other antibiotics because tigecycline therapy had failed and/or resistant pathogens were present. In the ten recovered patients who continued on tigecycline, improvement was documented as occurring within two to seven days, with full recovery observed between six and 22 days.
Tigecycline's adverse events include: nausea and vomiting $(n=4)$; diarrhea $(n=2)$; and hypotension $(n=1)$. These mostly appeared on the first or second day of tigecycline treatment. None of these adverse drug reactions led to tigecycline discontinuation or treatment change. Patients' clinical outcomes varied and were extremely difficult to associate with tigecycline efficacy because of the influences of confounding factors, including severity and stage of infection, comorbidities, and concurrent antimicrobial therapy. The documented adverse events were

Table 4: Indication, treatment, and outcomes of patients commenced and continued on tigecycline $(n=10)$

\begin{tabular}{|c|c|c|c|c|}
\hline $\begin{array}{l}\text { Documented } \\
\text { indication(s) }\end{array}$ & Pathogen(s) & $\begin{array}{c}\text { Antimicrobials } \\
\text { added to tigecycline }\end{array}$ & $\begin{array}{c}\text { Days to } \\
\text { documented } \\
\text { symptom } \\
\text { improvement }\end{array}$ & $\begin{array}{l}\text { Days to } \\
\text { documented } \\
\text { recovery }\end{array}$ \\
\hline $\begin{array}{l}\text { Severe } \\
\text { pneumonia }\end{array}$ & $\begin{array}{c}\text { Klebsiella } \\
\text { pneumoniae }\end{array}$ & $\begin{array}{l}\text { Vancomycin, } \\
\text { amikacin, } \\
\text { meropenem, } \\
\text { ribavirin, and } \\
\text { interferon } \alpha-2 a n\end{array}$ & 5 & 7 \\
\hline $\begin{array}{l}\text { Intra-abdominal } \\
\text { infection }\end{array}$ & $\begin{array}{c}\text { Acinetobacter } \\
\text { baumannii, } \\
\text { Escherichia } \\
\text { coli }\end{array}$ & $\begin{array}{l}\text { Meropenem and } \\
\text { caspofungin }\end{array}$ & 6 & 22 \\
\hline $\begin{array}{l}\text { Septic shock, } \\
\text { bilateral } \\
\text { pneumonia }\end{array}$ & $\begin{array}{c}\text { Serratia } \\
\text { marcescens }\end{array}$ & No & 7 & 14 \\
\hline $\begin{array}{l}\text { Acute } \\
\text { respiratory } \\
\text { failure with } \mathrm{CO}_{2} \\
\text { narcosis }\end{array}$ & $\begin{array}{l}\text { Multi-drug } \\
\text { resistant } \\
\text { Acinetobacter } \\
\text { baumannii }\end{array}$ & No & 7 & 14 \\
\hline $\begin{array}{l}\text { Interstitial } \\
\text { pulmonary } \\
\text { fibrosis, septic } \\
\text { shock }\end{array}$ & $\begin{array}{c}\text { Proteus } \\
\text { mirabilis, } \\
\text { Acinetobacter } \\
\text { baumannii, } \\
\text { Pseudomonas } \\
\text { aeruginosa }\end{array}$ & No & 5 & 8 \\
\hline Pneumonia & $\begin{array}{l}\text { Providencia } \\
\text { stuartii, } \\
\text { Serratia } \\
\text { marcescens }\end{array}$ & No & 5 & 8 \\
\hline $\begin{array}{l}\text { Diabetic foot } \\
\text { infection }\end{array}$ & $\begin{array}{c}\text { Acinetobacter } \\
\text { baumannii, } \\
\text { Escherichia } \\
\text { coli }\end{array}$ & $\begin{array}{l}\text { Meropenem and } \\
\text { metronidazole }\end{array}$ & 2 & 22 \\
\hline $\begin{array}{l}\text { Fever, malignant } \\
\text { neoplasm of the } \\
\text { nasopharynx }\end{array}$ & $\begin{array}{l}\text { Coagulase- } \\
\text { negative } \\
\text { Staphylococci, } \\
\text { non-albicans } \\
\text { Candida }\end{array}$ & Colistin & 3 & 6 \\
\hline $\begin{array}{l}\text { Urinary tract } \\
\text { infection, bed } \\
\text { sores }\end{array}$ & $\begin{array}{c}\text { Morganella } \\
\text { morganii, } \\
\text { Klebsiella } \\
\text { oxytoca }\end{array}$ & Amikacin & 5 & 12 \\
\hline $\begin{array}{l}\text { Septic shock, } \\
\text { catheter-related }\end{array}$ & $\begin{array}{l}\text { Multi-drug } \\
\text { resistant } \\
\text { Acinetobacter } \\
\text { baumannii }\end{array}$ & No & 4 & 7 \\
\hline
\end{tabular}


of low prevalence and severity, and were similar to those reported previously $[6,14]$. While lifethreatening adverse events have been noted with tigecycline $[16,18]$ and have resulted in safety warnings, it is unlikely that the high mortality observed in this study was directly attributable to tigecycline. Many patients included in this study died, irrespective of treatment, and few patients continued on tigecycline as the sole antimicrobial.

\section{Limitations of the study}

The small dataset and the potential reporting bias due to the reliance on case notes; are the major two limitations. It is possible that drug adverse events were underreported. Even when tigecycline is mostly prescribed in line with the relevant marketing authorizations, patient outcomes are complex and influenced by many confounding factors and may not necessarily be generalizable to the entire KSA.

\section{CONCLUSION}

The study revealed that tigecycline prescription was in line with the marketing authorizations and national guidelines. While many patients had poor outcomes, these could not be attributed solely to a lack of tigecycline efficacy or toxicity; confounding factors, including infection severity/stage and comorbidities may influence patients' outcomes.

\section{ACKNOWLEDGEMENT}

The authors would like to acknowledge the Ministry of Health and the Directors of the Directorate of Health Affairs in KSA for supporting this research. We would also like to extend our thanks to all the participating hospitals.

\section{REFERENCES}

1. Davies J, Dorothy D. Origins and evolution of antibiotic resistance. Microbiol Mol Biol Rev 2010; 74(3): 417-433.

2. Costelloe $C$, Metcalfe $C$, Lovering $A$, Mant $D$, Hay $A D$. Effect of antibiotic prescription in primary care on antimicrobial resistance in individual patients: systematic review and meta-analysis. Brit Med J 2010; 340: c2096.

3. Davey $P$, Brown E, Charani E, Fenelon L, Gould IM, Holmes A, Ramsay CR, Wiffen PJ, Wilcox $M$. Interventions to improve antibiotic prescription practices for hospital inpatients. Cochrane Database Syst Rev 2013; 4: CD003543.

4. Leibovici L, Paul M, Ezra O. Ethical dilemmas in antibiotic treatment. J Antimicrob Chemother 2012; 67: 12-16.
5. Paul M, Shani V, Muchtar E, Kariv G, Robenshtok E, Leibovici L. Systematic review and meta-analysis of the efficacy of appropriate empiric antibiotic therapy for sepsis. Antimicrob Agents Chemother 2010; 54: 48514863.

6. Fischbach MA, Walsh CT. Antibiotics for emerging pathogens. Science 2009; 325: 1089-1093.

7. Food and Drug Administration. FDA Approved Drug Products. Available at: http://www.accessdata.fda.gov/ scripts/cder/drugsatfda/index.cfm?fuseaction=Search.Dr ugDetails [Accessed Aug 2014].

8. Stein, Gary E., and William A. Craig. "Tigecycline: a critical analysis." Clin infect dis 2006; 43.4 : 518-524.

9. Dryden M. Tigecycline: an antibiotic for the twenty-first century. J Antimicrob Chemother 2013; 68(suppl 2): ii3ii4.

10. Brust K, Evans A, Plemmons R. Tigecycline in treatment of multidrug-resistant Gram-negative bacillus urinary tract infections: a systematic review. J Antimicrob Chemother 2014; 69(10): 2606-2610.

11. Tasina E, Haidich AB, Kokkali S, Arvanitidou M. Efficacy and safety of tigecycline for the treatment of infectious diseases: a meta-analysis. Lancet Infect Dis 2011; 11: 834-844.

12. Muralidharan G, Micalizzi M, Speth J, Raible D, Troy S. Pharmacokinetics of tigecycline after single and multiple doses in healthy subjects. Antimicrob Agents Chemother 2005; 49(1): 220-229.

13. MacGowan AP. Tigecycline pharmacokinetic/ pharmacodynamic update. I Antimicrob Chemother 2008; 62(suppl 1): i11-i16.

14. Cai Y, Wang R, Liang B, Bai N, Liu Y. Systematic review and meta-analysis of the effectiveness and safety of tigecycline for treatment of infectious disease. Antimicrob Agents Chemother 2011; 55(3): 1162-1172.

15. Sun Y, Cai $Y$, Liu X, Bai N, Liang B, Wang R. The emergence of clinical resistance to tigecycline. Int $J$ Antimicrob Agents 2013; 41(2): 110-116.

16. Food and Drugs Administration. Drug Safety Communication 2013. Increased risk of death with Tygacil (tigecycline) compared to other antibiotics used to treat similar infections. Available at: http://www.fda.gov/Drugs/DrugSafety/ucm369580.htm [Accessed Aug 2014].

17. Yahav D, Lador A, Paul M, Leibovici L. Efficacy and safety of tigecycline: a systematic review and metaanalysis. J Antimicrob Chemother 2011; 66: 1963-1971.

18. Prasad P, Sun J, Danner RL, Natanson C. Excess deaths associated with tigecycline after approval based on noninferiority trials. Clin Infect Dis 2012; 54(12): 16991709.

19. Kuo SC, Wang FD, Fung CP, Chen LY, Chen SJ, Chiang MC, Hsu SH, Liu CY. Clinical experience with tigecycline as treatment for serious infections in elderly and critically ill patients. J Microbiol Immunol Infect 2011; 44(1): 45-51.

20. Bassetti M, Eckmann C, Bodmann KF, Dupont $H$, Heizmann WR, Montravers $P$, Guirao X, Capparella MR,

Trop J Pharm Res, October 2015; 14(10): 1925 
Simoneau D, García MS. Prescription behaviours for tigecycline in real-life clinical practice from five European observational studies. I Antimicrob Chemother 2013; 68(supp/ 2): ii5-ii14.

21. Kingdom of Saudi Arabia Food \& Drug Authority. Drug Bulletin 2011; 2(3) Available at: http://www.sfda. gov.sa/ar/drug/resources/DocLib1/Volume\%202/lsue3Hi gh.pdf. [accessed Aug 2014].

22. Knaus WA, Draper EA, Wagner DP, Zimmerman JE. "APACHE II: a severity of disease classification system". Critical Care Medicine 1985; 13 (10): 818-29.

23. Shin JA, Chang YS, Kim HJ, Kim SK, Chang J, Ahn CM, Byun MK. Clinical outcomes of tigecycline in the treatment of multidrug-resistant Acinetobacter baumannii infection. Yonsei Med J 2012; 53(5): 974-84.

24. Karageorgopoulos DE, Kelesedis T, Kelesedis I, Falagas ME. Tigecycline for the treatment of multidrug-resistant (including carbapenem resistant) Acinetobacter infections: a review of the scientific evidence. J Antimicrob Chemother 2008; 62: 45-55.

25. Baadani AM, Thawadi SI, El-Khizzi NA, Omrani AS. Prevalence of colistin and tigecycline resistance in Acinetobacter baumannii clinical isolates from 2 hospitals in Riyadh Region over a 2-year period. Saudi Med J 2013; 34(3): 248-253.

26. Al-Qadheeb NS, Althawadi S, Alkhalaf A, Hosaini S, Alrajhi $A A$. Evolution of tigecycline resistance in Klebsiella pneumoniae in a single patient. Ann Saudi Med 2010; 30(5): 404-407.

27. Hornsey $M$, Ellington $M J$, Doumith $M$, Hudson $S$, Livermore DM, Woodford N. Tigecycline resistance in Serratia marcescens associated with up-regulation of the SdeXY-HasF efflux system also active against ciprofloxacin and cefpirome. J Antimicrob Chemother 2010; 65(3): 479-482.

28. Ruzin A, Visalli MA, Keeney D, Bradford PA. Influence of transcriptional activator RamA on expression of multidrug efflux pump $A c r A B$ and tigecycline susceptibility in Klebsiella pneumoniae. Antimicrob Agents Chemother 2005; 49: 1017-1022.

29. Roy S, Datta S, Viswanathan R, Singh AK, Basu S. Tigecycline susceptibility in Klebsiella pneumoniae and Escherichia coli causing neonatal septicaemia (20072010) and role of an efflux pump in tigecycline nonsusceptibility. J Antimicrob Chemother 2013; 68(5): 1036-1042. 